\title{
INFLUENCE OF INNOVATION, COMPLEXITY AND NEWNESS ON SUCCESS IN NEW PRODUCT DEVELOPMENT PROJECTS: A SURVEY IN NORWEGIAN MANUFACTURING INDUSTRY
}

\author{
C. Beste ${ }^{凶}$, T. Welo and N. Olsson \\ Norwegian University of Science and Technology, Norway \\ $\triangle$ carina.beste@ntnu.no
}

\begin{abstract}
There is little tolerance for deviation in time, budget and quality in the execution of product development projects. On the other hand, the project environment is gaining complexity. Changes on project scope are daily business. We set up an initial hypothesis, that unplanned changes newness- has negative impact on projects. We developed and executed therefore a survey about factors belonging to innovation, complexity and newness to test their perceived impact on project success. Our data show a positive correlation between unsuccessful projects and newness, which is discussed in the paper.
\end{abstract}

Keywords: innovation management, project management, new product development, complexity, performance indicators

\section{Introduction}

Customers today can choose between many options as products and services are getting increasingly interchangeable and often lose their unique identification. Vernon already argued in 1966 that products experience different stages during their lifecycle (1966). The late phase called 'maturity' is characterized with sales volume peaks, decreasing market share and profit due to stronger competition, followed by cost reductions cycles (Pichler, 2016). This phase show some similarities to those of a classical commodity business, which can be defined as: 'In economics, a commodity is an economic good or service that has full or substantial fungibility; that is, the market treats instances of the good as equivalent or nearly so with no regard to who produced them' (Cennon, 2019). This implies that parts of the businesses are drifting more and more towards a commodity business (Enke et al., 2014).

This trend is expected to continue in the future, as the business conditions are getting more competitive, globally interconnected and faster. PMI's PMBOK ${ }^{\circledR}$ summarises generally accepted project management practices, including best practice processes (2017), and lays the foundation for critical success factors in project management. Pinto and Slevin $(1987,1988)$ made classical work on success factors of projects, identifying three key general factors; technical validity, organisational validity and organisational effectiveness. The focus on cost, time and quality is known as the classical triangle in program management and has been used intensively since the 50s. 'Project management success' is rated among these factors while 'project success' itself can be rated completely different (Cooke-Davies, 2002). Pinto et al. (2000) highlights that successful strategic project management project depends on an organization's 
ability to satisfy customer requirements. Process-driven projects are regularly identified with a high grade of robustness, reliability, repeatability and a fixed value potential. This type of projects is characterized in the research from Shenhar as 'A-Low tech, 1-assembly engineering project'. The opposite is explorationdriven projects, which are usually characterized by ambiguity, uniqueness, newness and unlimited value potential. Research described the difference as 'Exploration and Exploitation Capabilities' in firms, see Figure 1 which is based on Beste et al. (2019). During the entire development of a project, internal and external stakeholders tend to push the borders more and more towards the exploration-driven projects. Moreover, the overall project landscape is getting more and more complex (Baccarini, 1996). We cluster influential factors pushing the boundaries from exploitational to an explorational project after Shenhar and Yalcinkaya as innovation, complexity and newness. In industry, these factors are often underestimated and needs to be 'successfully' managed from the Product Development (PD) team for the most part without adapting the targets for costs, time and quality.

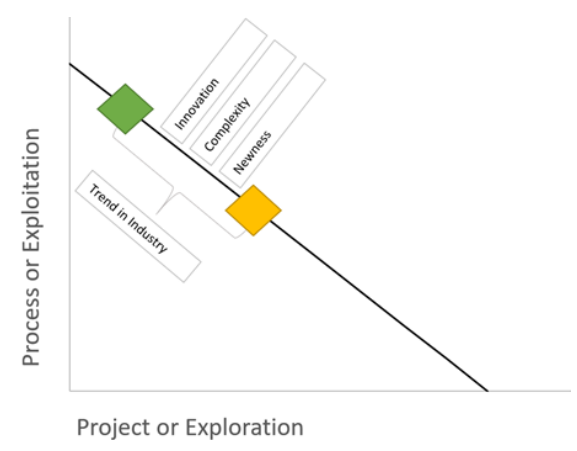

Figure 1. Trend in industry

This may lead into challenges and contradictions for the PD team itself which need to be better understood in terms of their impact on project success. Out of this problem, we formulated the following hypothesis: 'In a process-driven world, where costs, time and quality dictate the success of a project, newness during PD has a negative impact on project success itself'

The overall target is to validate this hypothesis. The underlying research questions related to the above are as follows:

- 'Which are more important success factors in projects?'

- 'Which are less important success factors in projects?'

- 'What is the influence of complexity and innovation on project success?'

To address these research questions, the remainder of the paper continues with theoretical background with focus on definitions of innovation, complexity and newness as a basis. In Section 3, the research method is presented, including the development of a survey. Section 4 presents the results, followed by the discussion and the conclusion in Section 5.

\section{Theoretical background}

\subsection{Definition of innovation}

As innovation is a fashionable and iridescent concept, it is necessary to define innovation more precise (Hauschildt et al., 2016). Projects are usually confronted with different types of innovation during the execution phase. Based mainly on Schumpeter's research (1934), Johannessen and his group divided innovation into six dimensions, including new products, new services, new methods of production, opening new markets, new sources of supply, and new ways of organizing.

The request for innovation in process-focused projects is driven from different stakeholders starting usually with a simple change. These changes do not need to be new-to-the-world. The definition from Rogers and Shoemaker, 'An Innovation is an idea, practise or object perceived as new by the individual. It matters little, as far as human behaviour is concerned, whether or not an idea is objectively new as measured by the lapse of time since its first use or discover. If the idea seems new and different to the individual, it is an innovation.' underline our understanding of innovation. (1971). 


\title{
2.2. Definition of complexity
}

The topic complexity is also highly related to performance of project management. Here we adopt the definition of complexity due to Vidal et al. (2011): "Project complexity is the property of a project which makes it difficult to understand, foresee and keep under control its overall behaviour, even when given reasonably complete information about the project system."

There are many different definitions of 'complexity drivers' in the literature (Vogel and Lasch, 2016), who proposed the following definition:

\begin{abstract}
"Complexity drivers are factors, which influence a system's complexity and company's target achievement. They are responsible for increasing system's complexity level and help to define the characteristics or the phenomenon of a system's complexity. Complexity drivers are influenced by one another, that is by internal or external drivers, and cannot be reduced completely to another one."
\end{abstract}

The separation from Marle and Vidal between different system levels in projects (2016) seems to be most suitable to fit our research because of the usage of different system levels which can be used very modular for different sort of projects.

Table 1. Project complexity framework after Marle and Vidal (2016)

\begin{tabular}{lll}
\hline System Level & Organizational Complexity & Technological Complexity \\
\hline Project System Size & No. of objectives & Resources \\
& No. of stakeholders & Scope \\
Project System Variety & $\ldots$ & $\ldots$ \\
& Diversity of staff & Product Variety \\
& Variety methods and tools applied & Technological Variety \\
Interdependencies [In.] within project & $\ldots$ & $\ldots$ \\
& In. of shared resources & In. in products \\
& Team Cooperation & In. of processes \\
Elements of context & $\ldots$ & $\ldots$ \\
& Culture & Competition \\
& Degree of Innovation & Laws and regulations
\end{tabular}

\subsection{Definition of newness}

We have chosen to use the term 'newness', which may need some clarification and comparison with other related terms. Newness or unplanned and 'unexpected' changes is a less understood field of innovation. Caron figured out that, 'it is inevitable that unanticipated events will occur in projects, consequently requiring a time pressured response' (Caron, 2013). Change management itself is an established part of project management (Kerzner, 2013). Changes are a well-known cause of project problems, including cost overruns and delays (Hanna et al., 2002), even when changes are daily business in a PD lifecycle of a project. Changes can cause rework. Love et al. (2004) discuss rework as a result of causes such as errors, omissions, and change orders throughout the project. Caron identified based on the research of Geraldi (2008) the following categories in which unplanned and unexpected events can be divided:

- technical issues

- sponsor withdrawing support

- external events

- resource change or constraint

- human behavior

- $\quad$ project scope

Newness in the form of unplanned changes is partially related to scope creep, based on Caron's research referring to changes, continuous or uncontrolled growth in a project's scope, at any point after the project begins (Lewis, 2002). It is common to discuss the accumulation of project changes as scope creep due to a tendency that changes often relate to expansions rather than reductions of project scope. This phenomenon is overall considered as harmful. 
In the literature the usage of different terms for 'unexpected events' or 'newness' with similar meanings is very common. The difference between innovation, complexity, scope creep and newness is summarized in Table 2.

Table 2. Definitions of different terms regarding change, novelty, planned and foreseen

\begin{tabular}{|l|l|l|l|l|}
\hline Term & Change & Novelty & Planned & Foreseen \\
\hline Innovation & Yes & yes & yes & yes \\
\hline Complexity & No & no & no & yes \\
\hline Scope creep & yes & no & no & no \\
\hline Newness & yes & yes & no & no \\
\hline
\end{tabular}

Here our understanding of newness is that these include unplanned changes in the project, product or process environment.

Our assumption is that newness, in the meaning of unplanned, unforeseen changes of the content of projects, which contain novelty for the PD team leads to reduced performance in the project itself.

\section{Methods}

The test of our assumption was be done by studying the success of 25 statements aiming to cover the area of innovation, complexity and newness. The strategy is to survey (perceived) successfulness of projects in Norwegian manufacturing companies (Newcomer et al., n.d.). As the interpretation of the terms projects, success, innovation and newness is crucial we made an additional step before handing over the survey (See 3.1). The survey was done in workshops with Norwegian manufacturing companies in July 2019. The survey included 25 statements divided into 3 different areas (innovation, complexity and newness) evaluated on a Likert scale. A 7-point Likert scale was used where the employees could answer between 1 (no or very little compliance) to 7 (full or very much compliance). This was done for each individual statement. Overall, 23 participants answered 25 questions providing 575 individual data points. The 23 participants worked mainly for aluminium and construction manufacturers. These industries with a highly competitive market background are mainly covered in this study. We calculated the values for not successful projects out of the data for successful projects, in total 1,150 data points. At the end, 459 single data points (individual answers) out of 575 possible data points were available, indicating a loss of $20 \%$ of the data. Questions about newness indicate an average loss of $25 \%$. Question about innovation around $17 \%$.

\subsection{Understanding the terms - first part of the survey}

As the interpretation of the terms projects, success, innovation and newness is crucial for the comparability as well as the meaningfulness of the results, we ask the participants before starting with the survey to consider the following definitions according to our understanding of terms:

- Projects: as a process in which you developed a product, service or result (PMI, 2017).

- Success: as meeting targets in terms of quality, time and budget established at the beginning of the project or modified at later stage (Cooke-Davies, 2004).

- Innovation: as a change planned in advance that involves the creation of something new.

- Newness: as those unplanned or unexpected changes during the development of a project (Caron, 2013).

\subsection{Clustering innovation, complexity and newness - main part of the survey}

The main part of the survey contains 25 statements, which were evaluated from the participants in a 7point Likert scale. The statements Q1-Q7 quantify the level of innovation in the product, process and market. The statements from Q8-Q15 are about the impact of complexity. The statements from Q16Q25 cover the field donated newness. The next subsections are about the work which had been done to develop the 'right' statements for each area. In general, we proceeded in three steps to find the 'right' statements to be evaluated in the survey. 
a) Step 1: using suitable framework out of current literature to development concrete topics for the survey for each considered area (innovation, complexity, newness).

b) Step 2: validate the chosen topics with senior program managers, leading development engineers and experienced professors to adapt to real world situations and problems.

c) Step 3: redefine the topics with input from both academia as well as industry, and merge them to the final 25 statements

\subsubsection{Innovation}

For formulating the innovation statements used in the survey, we focused on the six innovation areas identified by Johannessen et al. (2001).

The concrete topics used in Table 3, developed out of the framework from Johannesen, had been later used as a base for the concrete statements in the survey (Table 4).

Table 3. Innovation areas (Johannessen et al., 2001) and chosen topics

\begin{tabular}{|l|l|}
\hline Innovation Area & Concrete Topics \\
\hline New products & Minor innovation of the product \\
\hline New methods of production & Innovative and new production method/process \\
\hline Opening new markets & Targeting different customer \\
\hline New services & Additional innovative services to the customers or employees \\
\hline New ways of organizing & Innovative change in the way of working \\
\hline New sources of supply & Innovative change regarding your sources of supply \\
\hline
\end{tabular}

Table 4. Concrete statements chosen in the survey for covering innovation

\begin{tabular}{|c|c|c|}
\hline Qu. & Statements Used In The Survey & Inno. Area \\
\hline Q1 & $\begin{array}{l}\text { Consider projects where you developed a minor innovation of the product. } \\
\text { (Example: Same product but different material, or different geometry or function) }\end{array}$ & new products \\
\hline Q2 & Consider projects in which you used an innovative production method/process. & $\begin{array}{l}\text { new production } \\
\text { methods }\end{array}$ \\
\hline Q3 & Consider projects that targeted on a different customer than your regular one. & different customer \\
\hline Q4 & $\begin{array}{l}\text { Consider projects that provide additional innovative services to the customers. } \\
\text { (Example: Additional cost breakdowns, preparation of alternative technical } \\
\text { solutions or similar activities) }\end{array}$ & new services \\
\hline Q5 & $\begin{array}{l}\text { Consider projects where there was a change of IT services, such as computer } \\
\text { programs, network equipment or servers you used. }\end{array}$ & new services \\
\hline Q6 & $\begin{array}{l}\text { Consider projects in which you made an innovative change in the way of working. } \\
\text { (Example: Organization of your department, communication strategy, etc. ) }\end{array}$ & $\begin{array}{l}\text { new ways of } \\
\text { organizing }\end{array}$ \\
\hline Q7 & $\begin{array}{l}\text { Consider projects in which you made an innovative change regarding your sources } \\
\text { of supply. (Example: Testing new suppliers, change of routines how to work with } \\
\text { suppliers) }\end{array}$ & $\begin{array}{l}\text { new sources of } \\
\text { supply }\end{array}$ \\
\hline
\end{tabular}

\subsubsection{Complexity}

Based on Marle's and Vidal's research, which distinguished complexity on different systems levels, we developed specific topics (Table 5) for formulating the complexity statements presented in the survey (Table 6).

Table 5. Focus areas in complexity after Marle and Vidal (2016)

\begin{tabular}{|l|l|}
\hline System Level & Concrete Topic \\
\hline Project System Size & $\begin{array}{l}\text { Perceived the number of objectives } \\
\text { Concerned parties }\end{array}$ \\
\hline Project System Variety & $\begin{array}{l}\text { Large number of hierarchical levels. } \\
\text { Using of more technological tools than usual. }\end{array}$ \\
\hline $\begin{array}{l}\text { Interdependencies [In.] } \\
\text { within project }\end{array}$ & $\begin{array}{l}\text { Share crucial resources with other projects or functional departments. } \\
\text { Product specifications } \\
\text { Customer needs were difficult to understand }\end{array}$ \\
\hline Elements of context & Different cultures with different manners and native languages \\
\hline
\end{tabular}


Table 6. Statements chosen in the survey for covering complexity

\begin{tabular}{|c|c|c|}
\hline Qu. & Concrete Statements Used In The Survey & System Level \\
\hline Q8 & $\begin{array}{l}\text { Consider projects in which you perceived the number of objectives to fulfil was very } \\
\text { high. }\end{array}$ & \multirow[t]{2}{*}{$\begin{array}{l}\text { Project System } \\
\text { Size }\end{array}$} \\
\hline Q9 & Consider projects in which the number of concerned parties was very high. & \\
\hline Q10 & Consider projects in which there were a large number of hierarchical levels. & \multirow{2}{*}{$\begin{array}{l}\text { Project System } \\
\text { Variety }\end{array}$} \\
\hline Q11 & $\begin{array}{l}\text { Consider projects where you used more technological tools than usual. (Example: You } \\
\text { used } 8 \text { machines instead of } 3 \text { or more computer programs than usual) }\end{array}$ & \\
\hline Q12 & $\begin{array}{l}\text { Consider projects in which you had to share crucial resources with other projects or } \\
\text { functional departments. }\end{array}$ & \multirow{3}{*}{$\begin{array}{l}\text { Interdependenci } \\
\text { es within } \\
\text { project }\end{array}$} \\
\hline Q13 & $\begin{array}{l}\text { Consider projects where product specifications were more difficult t } \\
\text { because of interdependencies. (Example: Bigger diameter and less } \mathrm{w}\end{array}$ & \\
\hline Q14 & $\begin{array}{l}\text { Consider projects where the customer needs were more difficult to understand than } \\
\text { usual. }\end{array}$ & \\
\hline Q15 & $\begin{array}{l}\text { Consider projects where you worked with people from different cultures with different } \\
\text { manners and native languages }\end{array}$ & $\begin{array}{l}\text { Elen } \\
\text { cont }\end{array}$ \\
\hline
\end{tabular}

\subsubsection{Newness}

As stated above, newness is considered as those unplanned or unexpected changes during the development of a project (Caron, 2013). For formulating the concrete statements used in the survey to cover newness, we used the same methodology as for innovation because of the similarities between both fields (Johannessen et al., 2001). We combined the six innovation areas from Johannessen with the framework from Marle and Vidal (2016). We merged this framework with former work by Geraldi (2008). She identified categories, in which 'unexpected changes' can be usually divided. The categories as well as the refined statements together with industry partners can be found in Table 7 .

Table 7. Statements chosen in the survey for covering newness (Geraldi, 2008)

\begin{tabular}{|c|c|c|}
\hline Qu. & Concrete statements used in the survey to cover newness & Category \\
\hline Q16 & $\begin{array}{l}\text { Consider projects in which people with less experience in the field hold positions of high } \\
\text { responsibility. (Example: Senior management position without direct involvement in the } \\
\text { project development team) }\end{array}$ & $\begin{array}{l}\text { Human } \\
\text { behaviour }\end{array}$ \\
\hline Q17 & $\begin{array}{l}\text { Consider projects in which people with less experience in the field hold positions of } \\
\text { normal responsibility. (Example: Design engineer inside the product development team) }\end{array}$ & $\begin{array}{l}\text { Human } \\
\text { behaviour }\end{array}$ \\
\hline Q18 & $\begin{array}{l}\text { Consider projects where the same team worked on the project for a period of time and } \\
\text { then certain key members were changed. }\end{array}$ & $\begin{array}{l}\text { Resource } \\
\text { change }\end{array}$ \\
\hline Q19 & $\begin{array}{l}\text { Consider projects in which there was a late change of suppliers due to emergency } \\
\text { situation. (Example: Suppliers not able to deliver and need to be replaced immediately) }\end{array}$ & $\begin{array}{l}\text { Technical } \\
\text { issues }\end{array}$ \\
\hline Q20 & $\begin{array}{l}\text { Consider projects in which there was a late change of suppliers due to late cost } \\
\text { optimization. (Example: Purchase department decided to change the supplier due to cost } \\
\text { savings or change of strategy) }\end{array}$ & $\begin{array}{l}\text { Project } \\
\text { scope }\end{array}$ \\
\hline Q21 & $\begin{array}{l}\text { Consider projects where there were some customer requested changes in product } \\
\text { specifications and the sales team approached the customer to sell these changes. }\end{array}$ & $\begin{array}{l}\text { External } \\
\text { events }\end{array}$ \\
\hline Q22 & $\begin{array}{l}\text { Consider projects in which you had to change some characteristics of the product } \\
\text { because of your competitors. (Example: Competitors design is cheaper) }\end{array}$ & $\begin{array}{l}\text { External } \\
\text { events }\end{array}$ \\
\hline Q23 & Consider projects in which the customers changed their requirements late in the project. & $\begin{array}{l}\text { Project } \\
\text { scope }\end{array}$ \\
\hline Q24 & $\begin{array}{l}\text { Consider projects where the machinery/production method/setup had to be changed a lot } \\
\text { because deviations (Examples: Tolerances were not precise enough, components had to } \\
\text { be replaced in the last minute, workers don't reach the cycle time, additional content } \\
\text { needs to be implemented, capacity is not enough to reach the requested volume etc.). }\end{array}$ & $\begin{array}{l}\text { Technical } \\
\text { issues }\end{array}$ \\
\hline Q25 & $\begin{array}{l}\text { Consider projects in which you had to deal with late and unexpected changes in the } \\
\text { organization of your department and/or business strategy of the company. }\end{array}$ & $\begin{array}{l}\text { External } \\
\text { events }\end{array}$ \\
\hline
\end{tabular}




\section{Results}

After the workshop attendees completed the surveys, the questionnaire was collected, and the data evaluated in Excel. In a first step the average had been calculated for the samples 'successful' $\left(\overline{\mathrm{x}}_{\mathrm{ks}}\right)$.

$$
Q\left(\bar{x}_{k s}\right)=\frac{1}{n} \sum_{k=1}^{n} a_{k}
$$

Here $\mathrm{n}$ is number of measurement points (25), $\mathrm{k}$ is an integer representing the individual question and $\mathrm{a}$ is the individual data point for response $\mathrm{k}$.

For calculating the related datapoint for 'not successful' projects $\left(\bar{x}_{\mathrm{ku}}\right)$, we were using following formula.

$$
\overline{\mathrm{x}}_{\mathrm{ku}}=7-\overline{\mathrm{x}}_{\mathrm{ks}}+1
$$

Here the average mean of samples 'successful' is denoted $\overline{\mathrm{x}}_{\mathrm{ks}}$. The result is shown in Figure 2.

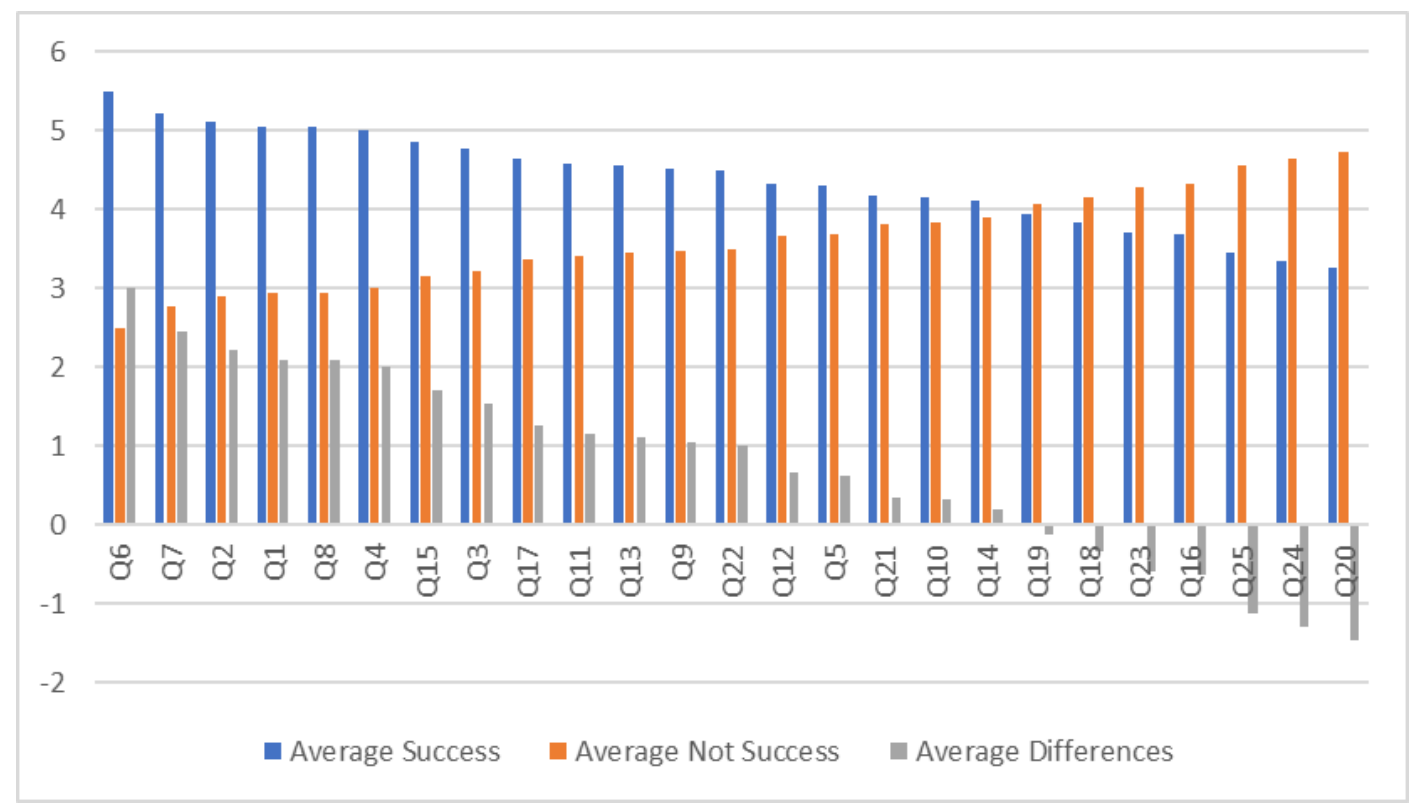

Figure 2. Sorted result of the survey, including average means

In the next step, we asked: Which topics/questions have the bigger impact on projects related to success and are therefore more important?

To answer the questions, we first calculated the crucial point as represented by the average difference $\left(\overline{\mathrm{x}}_{\mathrm{kd}}\right)$ between the means of the two samples 'successful' and 'not successful' projects (Keller, 2014):

$$
\overline{\mathrm{x}}_{\mathrm{kd}}=\overline{\mathrm{x}}_{\mathrm{ks}}-\overline{\mathrm{x}}_{\mathrm{ku}}
$$

We first sorted the average differences to identify the biggest positive and negative correlation successful and not successful projects in Figure 2.

It is logical that questions with a higher deviation (positive as well as negative) has a bigger influence on the success of projects than other questions with less deviation. The statistics show that $\bar{x}_{\mathrm{kd}}$ is 0.77 for all 25 questions. The summary in Table 8 shows the most important factors.

Table 8. Most Important factors on the success of projects

\begin{tabular}{|l|l|}
\hline Successful projects & Unsuccessful projects \\
\hline Q6 innovative change in way of working & Q20 late supplier change due to cost reasons \\
\hline Q7 innovative change in supply & Q24 changing in production setups \\
\hline Q2 innovation in production process & Q25 changes in organisation or business strategy \\
\hline
\end{tabular}


In the following examination, it has been decided to concentrate on the questions that are most important on project success.

\subsection{Most important factors for success of projects}

Differences between successful and not successful projects were identified for innovative change in way of working (Q6, Innovation), innovate change in sources of supply (Q7, Innovation) and innovation in production process (Q2, Innovation). Innovative and new ways of working had been considered as extremely positive with an average mean of +3 . This in in accordance to current research regarding white-collar productivity even when there is surprisingly few studies on these topic done yet (Laihonen et al., 2012). New ways of working are considered to increase employees job satisfaction, working motivation and most importantly their productivity (Peponis et al., 2007; Veitch et al., 2007; Vuolle, 2010). Productivity and working motivation leads to project success (Cooper, 2001). Innovative changes in source of supply had been rated with +2.44 . New ways in organising external supply chain is needed to archive advantages in prices, optimized quality and shorter lead times (Chopra and Meindl, 2007). Using innovative production methods had been rated with an average mean of $+2,21$ and are therefore the third most important factor on success of projects. Process innovations are seen in literature as efficiency increasing methods for producing known products cheaper, faster or better (Hauschildt et al., 2016) especially in competitive business environment (Utterback and Abernathy, 1975) or as enabler for producing new products.

\subsection{Most important factors for failures in projects}

The three most important pitfalls in PD projects identified by the participants were 'late supplier changes due to cost reasons' (Q20. Newness), 'changes in machinery/production due to deviations' (Q24, Newness) and 'unplanned changes in organisation' (Q25, Newness). Late supplier changes due to cost reasons had been identified as especially harmful with $-1,47$ average difference. Overall late changes in PD are costly (Iansiti, 1995) and therefor rated negatively to project success. Additionally, late changes due to cost reasons can be frustrating for the team (Invernizzi et al., 2018), as there is no technical necessity for the change. On the other hand, late supplier changes due to emergency situations (Q19, Newness) had been rated almost neutral on project success (-0,125 average difference) and therefore underline the conclusion above. As Amason et al. (1995) figured out, conflicts in teams can be positive or negative. Changes in machinery/production due to deviation in the setup is rated with $-1,29$ average difference. In other words, projects with less change in the production set-up due to deviations are typically more successful. The average difference of -1.11 implies that 'unplanned and unexpected changes in organisations itself or business strategies' (Q25) have a negative impact on success as well.

\subsection{Limitations}

The survey had been done with 23 participants from different manufacturing companies in Norway, and the individuals may have interpreted the definition of successful subjectively, even if the terms and conditions of 'successful' projects were explained as a part of the study. The participants could have more or less conscious different individual definitions, which could affect the scores.

\section{Conclusion and further work}

Our results merge quantitative data from practitioners working in real-world projects with classical innovation and complexity frameworks from academia. We introduce (and define) the term newness. Our findings also identify more important and less important topics related to project success in the considered areas of innovation, complexity and newness. 'Project success' in PD is much more than the traditional approach in project management of keeping time, budget and quality under control. Nevertheless, these three basic dimensions are still a very powerful instrument to measure project success. To proceed exploitational development projects as efficient as possible, a stable and repeatable development environment is needed. On the other hand, innovations and newness are parts of the daily business in a complex world. Our data shows a positive correlation between successful project outcome and innovation. Especially the topics 'changing of way of working' (Q6), 'innovative 
change in supply' (Q7) and 'innovations in productions processes' (Q2) had been rated positively on project success. Our data shows on the other hand that there is clearly a negative correlation between successful project outcome and newness. Especially 'late changes in supplier due to cost reasons' (Q20), 'changing in production setups due to deviations' (Q24) and 'unexpected changes in organisation or business strategy of the company' (Q25) had been rated as harmful to project success.

In overall we hadn't been able to falsify our initial hypothesis, that newness has a negative impact on project success. This raises several questions to be addressed in current and in further research; for example: Which typical 'project events' tends to have a positive, neutral or negative effect on project success? How can such positive events be created; how can the negative event be avoided? The main practical implication of the study is to provide input to addressing these questions. Further work will furthermore aim to verify the results with a larger sample. We will use case studies and interviews in international companies to triangulate the data between different methods and compare the results.

\section{References}

Amason, A.C. et al. (1995), "Conflict: An important dimension in successful management teams", Organ. Dyn., Vol. 24, pp. 20-35. https://doi.org/10.1016/0090-2616(95)90069-1

Baccarini, D. (1996), "The concept of project complexity - a review”, Int. J. Proj. Manag., Vol. 14, pp. 201-204.

Beste, C., Welo, T. and Ringen, G. (2019), "Newness and Outcomes in Commodity-Driven New-Product Development Projects: A Survey in the Norwegian Manufacturing Industry", Procedia CIRP, Vol. 84, pp. 749754. https://doi.org/10.1016/j.procir.2019.03.269

Caron, F. (2013), Managing the Continuum: Certainty, Uncertainty, Unpredictability in Large Engineering Projects, Springer, Milano.

Cennon, J. (2019), What Are Commodities and How Do You Trade Them? 2019.

Chopra, S. and Meindl, P. (2007), Supply chain management: strategy, planning, and operation, 3rd ed. Pearson/Prentice Hall, Upper Saddle River, NJ.

Cooke-Davies, T. (2004), Project Success, in: The Wiley Guide to Managing Projects. pp. 99-122.

Cooke-Davies, T. (2002), “The 'real' success factors on projects”, Int. J. Proj. Manag., Vol. 20, pp. 185-190. https://doi.org/10.1016/S0263-7863(01)00067-9

Cooper, R.G. (2001), Winning at new products: accelerating the process from idea to launch, 3rd ed. Perseus Pub, Cambridge, Mass.

Enke, M., Geigenmüller, A. and Leischnig, A. (Eds.) (2014), Commodity Marketing: Grundlagen, Besonderheiten, Erfahrungen, 3., aktual. und erw. Aufl. ed. Springer Gabler, Wiesbaden.

Geraldi, J.G. (2008), "The balance between order and chaos in multi-project firms: A conceptual model”, Int. J. Proj. Manag., Vol. 26, pp. 348-356. https://doi.org/10.1016/j.ijproman.2007.08.013

Hanna, A.S. et al. (2002), "Quantitative Definition of Projects Impacted by Change Orders", J. Constr. Eng. Manag., Vol. 128, pp. 57-64. https://doi.org/10.1061/(ASCE)0733-9364(2002)128:1(57)

Hauschildt, J. et al. (2016), Innovationsmanagement, 6., vollständig aktualisierte und überarbeitete Auflage. ed, Vahlens Handbücher, Verlag Franz Vahlen, München.

Iansiti, M. (1995), "Shooting the Rapids: Managing Product Development in Turbulent Environments", Calif. Manage. Rev., Vol. 38, pp. 37-58. https://doi.org/10.2307/41165820

Invernizzi, D.C., Locatelli, G. and Brookes, N.J. (2018), "The need to improve communication about scope changes: frustration as an indicator of operational inefficiencies", Prod. Plan. Control.

Johannessen, J.-A., Bjørn, O. and Lumpkin, G.T. (2001), "Innovation as newness: what is new, how new, and new to whom?”, Eur. J. Innov. Manag., Vol. 4, pp. 20-31.

Keller, G. (2014), Statistics for management and economics.

Kerzner, H. (2013), Project management: a systems approach to planning, scheduling, and controlling, Eleventh edition. John Wiley \& Sons, Inc., Hoboken, New Jersey.

Laihonen, H. et al. (2012), "Measuring the productivity impacts of new ways of working", J. Facil. Manag., Vol. 10, pp. 102-113. https://doi.org/10.1108/14725961211218749

Lewis, J.P. (2002), Fundamentals of project management: developing core competencies to help outperform the competition, 2nd ed. AMACOM, New York.

Love, P.E.D., Irani, Z. and Edwards, D.J. (2004), “A Rework Reduction Model for Construction Projects”, IEEE Trans. Eng. Manag., Vol. 51, pp. 426-440. https://doi.org/10.1109/TEM.2004.835092

Marle, F. and Vidal, L.-A. (2016), Managing complex, high risk projects: a guide to basic and advanced project management, Engineering.

Newcomer, K.E., Hatry, H.P. and Wholey, J.S. (n.d.), “Chapter Fourteen Using Surveys”, in: Handbook of Practical Program Evaluation, Essential Texts for Nonprofit and Public Leadership and Management. pp. 344-382. 
Peponis, J. et al. (2007), "Designing Space to Support Knowledge Work", Environ. Behav. 39, pp. 815-840. https://doi.org/10.1177/0013916506297216

Pichler, R. (2016), Strategize: product strategy and product roadmap practices for the digital age.

Pinto J.K., Rouhiainen P. and Trailer J.W. (2000), "Project Success and Customer Satisfaction: Toward a Formalized Linkage Mechanism”, In: Lundin R.A. and Hartman F. (Eds) Projects as Business Constituents and Guiding Motives, Springer, Boston, MA.

Pinto, J.K. and Slevin, D.P. (1987), "Critical factors in successful project implementation”, IEEE Transactions on Engineering Management, Vol. 34 No. 1, pp. 22-27.

Pinto, J.K. and Slevin, D.P. (1988), "Project success: Definitions and measurement techniques", Project Management Journal, Vol. XIX No. 1, pp. 67-71.

PMI 2017. Project Management Institute A guide to the project management body of knowledge, Sixth edition. Ed., PMBOK guide. Project Management Institute, Newtown Square, PA.

Rogers, E. and Shoemaker, F. (1971), Communication of innovations; a cross-cultural approach. Free Press.

Schumpeter, J.A. (1934), The theory of economic development; an inquiry into profits, capital, credit, interest, and the business cycle. Harvard University Press, Cambridge, Mass.

Utterback, J.M. and Abernathy, W.J. (1975), “A dynamic model of process and product innovation”, Omega Vol. 3, pp. 639-656. https://doi.org/10.1016/0305-0483(75)90068-7

Veitch, J.A. et al. (2007), "A model of satisfaction with open-plan office conditions: COPE field findings", $J$. Environ. Psychol., Vol. 27, pp. 177-189. https://doi.org/10.1016/j.jenvp.2007.04.002

Vernon, R. (1966), "International Investment and International Trade in the Product Cycle", Q. J. Econ. Vol. 80, pp. 190-207.

Vidal, L.-A., Marle, F. and Bocquet, J.-C. (2011), "Measuring project complexity using the Analytic Hierarchy Process", Int. J. Proj. Manag., Vol. 29, pp. 718-727.

Vogel, W. and Lasch, R. (2016), "Complexity drivers in manufacturing companies: a literature review", Logist. Res., p. 25.

Vuolle, M. (2010), "Productivity impacts of mobile office service", Int. J. Serv. Technol. Manag., Vol. 14, p. 326. https://doi.org/10.1504/IJSTM.2010.035782 